\title{
Gerakan Femen di Ukraina dalam Kritik Posmodern Feminisme Terhadap Posfeminisme
}

\author{
Dias Pabyantara S.M. \\ Universitas Pembangunan Nasional "Veteran" Surabaya
}

\begin{abstract}
This paper argues, posfeminist claims in post-199o about the absence of oppression of women by patriarchal structures is not entirely true. They are still there. One indication is the emergence of a topless movement called Femen. in Ukraine. They protest against three things: dictatorship, religious institutions and the sex industry. The emergence of the Ukrainian Femen at least supported by two things, domestic and international. Domestic factors consist of democratization and Barbie lifestyle emerging in Ukraine and international factors that include the globalization of information and the ratification of the International Convention CEDAW. These factors support the assumption about the emergence of Femen as postmodern, in a quadrant of the second wave of feminism. This movement has been falsely interpreted as the existence of oppression of female identity in the midst of patriarchal structure.
\end{abstract}

Keywords: Femen, Postmodern Feminism, Postfeminism, Ukraine.

Tulisan ini menemukan bahwa klaim posfeminisme pada era pasca 1990 tidak sepenuhnya benar. Bahwa opresi terhadap identitas perempuan oleh struktur sosial yang patriarki tetap terjadi. Salah satu indikasinya adalah kemunculan Femen sebagai gerakan topless di Ukraina yang memprotes tiga hal: diktatorisme, institusi keagamaan dan industry seks. Munculnya Femen di Ukraina setidaknya didukung oleh dua hal, domestik dan internasional. Faktor domestik terdiri dari demokratisasi dan Barbie lifestyle yang muncul di Ukraina dan faktor internasional yang meliputi globalisasi informasi dan ratifikasi konvensi Internasional CEDAW. Faktor-faktor tersebut mendukung kemunculan Femen sebagai gerakan feminisme posmodern, dalam kuadran feminisme gelombang kedua, yang kemudian diinterpretasi sebagai eksistensi opresi identitas perempuian terhadap struktur yang patriarki.

Kata-Kata Kunci: Femen, Feminisme Posmodern, Posfeminisme, Ukraina. 
Setidaknya terdapat tiga indikator yang mengindikasikan Femen merupakan manifestasi paradigma feminisme gelombang kedua, yaitu ditinjau dari dimensi ideologi sextremisme yang diartikulasikan Femen, cara protes yang dapat dikategorikan dalam kuadran postmodern strategy, dan konsepsi identitas yang diartikulasikan oleh Femen. Kelima indikasi tersebut yang menjadikan Femen sebagai salah satu indikasi bahwa gerakan perempuan dengan ciri gelombang kedua feminisme tidak serta merta menghilang dalam era yang sering dilabeli era posfeminisme.

\section{Pergeseran Makna Tubuh Dalam Feminisme Posmodern}

Dalam pemahaman feminisme posmodern, semua elemen tersebut mengkonstruksi makna bahwa struktur sosial dibangun di sekitar falus (Tong 1998, 292). Falus adalah rerpresentasi dari alat genital pria yang merupakan symbol dari penjajahan terhadap perempuan dalam pandangan feminis posmodern. Cixous menyampaikan bahwa semua kebudayaan yang sifatnya modern dibangun disekitar falus, sehingga secara langsung atau tidak berimplikasi terhadap representasi perempuan (Cixous dan Clement 1986, 63). Hal ini kemudian membuat pemaknaan terhadap perempuan, baik dalam konteks tubuh biologis maupun tubuh secara eksistensial distandarisasi melalui perspektif falus. Konstruksi yang terbentuk kemudian adalah bahwa tubuh perempuan adalah objek seks yang distandarasiasi menurut kesadaran falus (Cixous dan Clement 1986, 65).

Dengan adanya logika falus terhadap tubuh perempuan, maka hal ini memposisikan perempuan di posisi yang subordinatif, dalam konsep Beauvoir disebut liyan (Kaufmann 1979, 210). Bahwa laki-laki dengan falus dan perempuan adalah subordinasi terhadap falus menjadikan perempuan identitias yang teropresi dalam struktur sosial. Referensi mengenai tubuh perempuan sebagai simbol seks dan kepuasaan menurut standar falus menemukan poin pentingnya pada kisaran tahun 1960 awal, dengan indikasi terbitnya majalah pria dewasa Playboy (Pitzulo 2008, 259). Publikasi ini diklaim sebagai representasi terhadap konstruksi tubuh yang menggunakan logika falus. Ekspose terhadap tubuh perempuan untuk kegiatan yang sifatnya komersil pada masa itu dianggap sebagai opresi terhadap tubuh perempuan (Osgerby 2001, 145).

Pemahaman ini kemudian mengalami pergeseran pemaknaan. Dalam kaitannya terhadap gerakan sosial perempuan, tubuh perempuan tidak lagi menjadi hal yang sifatnya privat melainkan bergeser menjadi identitias yang sifatnya publik. Hal ini dapat diinterpretasikan melalui berkembangnya gerakan protes yang menggunakan tubuh sebagai alat 
untuk menyampaikan pesan. Beberapa gerakan protes telanjang seperti protes terhadap perang di Amerika Serikat, Afrika Selatan, Australia dan Kanada; protes terhadap kerusakan lingkungan dengan bersepeda telanjang dalam World Naked Bike Rides (Rallonza 2014, 255); dan gerakan protes telanjang pada saat World Social Forum tahun 2003 di Brazil (Sutton 2007, 140) menjadi indikasi berkembangnya gerakan protes telanjang pada era kekinian.

Munculnya banyak gerakan perempuan yang menggunakan tubuh sebagai alat protes setidaknya disebabkan oleh dua hal. Yang pertama standarisasi kualitas perempuan melalui ukuran-ukuran materialkomersial (Kis 2007, 34) pada saat yang sama juga klaim terhadap inefektivitas perjuangan perempuan melalui saluran lainnya sehingga perlu dikembangkan strategi baru untuk melawan penindasan struktur yang patriarki (Rallonza 2014, 259). Salah satu alternatif yang mengemuka adalah penggunaan tubuh untuk menyampaikan pesanpesan terhadap instrumen patriarki yang represif. Pergeseran pemaknaan terhadap tubuh perempuan dari domain privat menjadi domain publik memfasilitasi model perlawanan menggunakan tubuh untuk menemukan peranannya dalam struktur yang patriarki.

\section{Ideologi Sextrimisme Femen: Seksualitas Sebagai Alat Perlawanan Terhadap Patriarki}

Dalam konteks pergerakan perempuan Femen mengklaim diri menggunakan seksualitas sebagai senjata perlawanan (Shevchenko 2013a). Hal ini kemudian dilabeli sebagai ideologi sextrimisme. Pemahaman mengenai value ini kemudian diartikulasikan sebagai gerakan protes dengan menggunakan tubuh sebagai alat penyampaian pesan politik. Mengutip Inna Shevchenko (2015a),

"FEMEN's ideology is an absolute, the quest for an ideal society freed
from the binary and gendered conception of human relationships, in
which one could consider himself equal to any individual. We seek to
go beyond individual issues and cross cultural, political, national and
religious specificities. We seek to emancipate women and men from
the sexist mold that is imposed upon them by our society. That our
relations are governed by a single principle: equality. We proclaim
human beings' indivisibility."

Artikulasi Inna Shevchenko di atas setidaknya merepresentasikan dua hal. Yang pertama adalah bahwa ideologi sextremisme yang diartikulasikan oleh Femen menentang struktur sosial patriarki yang represif terhadap identitias perempuan dan yang kedua adalah artikulasinya mengenai keadaan yang setara antara perempuan dan lakilaki dalam masyrakat. Kedua nilai ini yang diartikulasikan Femen dalam 
setiap pergerakannya. Lebih lanjut lagi, Shevchenko menjelaskan artikulasi dari ideologi sextrimisme dengan menjelaskan tiga model represi terhadap perempuan oleh struktur sosial yang patriarki. Yang pertama adalah melalui kepemimpinan diktator, sistem keagamaan dan industri seks. Dari sini kemudian ideologi sextremisme membentuk identitas Femen sebagai pergerakan yang demokratis, ateis dan berdasarkan seksualitas perempuan.

Artikulasi identitas pergerakan Femen dapat diintepretasi dari pernyataan Shevchenko sebagai berikut ini, 'First, dictatorship, as a tool for enslaving women. For this reason we are a democratic movement." (Shevchenko 2013b). Dari pernyataan tersebut dapat diinterpretasikan bahwa Femen menginterpretasikan pergerakannya oposisi terhadap pemerintahan yang ortoriter. Otoriter yang dimaksud adalah terkait dengan ideologi dasar sextremisme yang menganggap seksualitas perempuan yang dimanifestasi dalam kebebasan menggunakan tubuhnya mendapat represi dari pemerintah. Pemerintahan Rusia dibawah Putin, Jerman dibawah Merkel dan Ukraina dibawah pemerintahan Presiden Yanikovich dianggap sebagai model pemerintahan diaktator (Shevchenko 2013c). Hal ini didasarkan pada pemahaman bahwa pemerintahan Putin melarang praktik homoseksual di Rusia (Bennet 2014) sedangkan Jerman tidak segera meloloskan Undang-Undang yang mengatur tentang pernikahan sesama jenis (Kirschbaum 2015). Sedangkan Presiden Yanukovich dilabeli sebagai diktator karena membatalkan perjanjian perdagangan dengan Uni Eropa dan lebih memilih mendekat secara diplomatik ke Rusia. Mayoritas opini publik Ukraina saat itu berasumsi bahwa tindakan Yanukovich ini karena mendapat tekanan dari Vladimir Putin di Rusia. Pada saat itu terjadi protes sebanyak 50.000 orang melakukan protes dan berakhir dengan kerusuhan di Kiev (Bacchi 2013).

Terkait dengan hal ini Femen mengidentifikasi pergerakannya sebagai pergerakan yang mendukung nilai-nilai demokratis, untuk menumbuhkan kesetaraan gender yang disampaikan sebelumnya dalam manifesto ideologi pergerakannya. Hal ini dimanifestasikan dalam aksi protes Femen pada 2013 dengan melakukan face to face protest terhadap Putin dan Merkel ketika keduanya bertemu di Hanover (Connoly 2014).

Setelah menyasar praktik diktatorisme, bagian kedua dari artikulasi pemahaman struktur patriarki oleh Femen adalah terkait dengan persepsi opresi dari institusi dan nilai-nilai keagamaan terhadap kesetaraan antara perempuan dan laki-laki. Mengutip Inna Shevchenko, "The second part of the system consists of religion and the church, which have overseen the spiritual enslavement of women. For this reason Femen is an atheistic group motivated by secularism and humanism." 
(Shevchenko 2013b) Dalam konteks ini, artikulasi pernyataan Shevchenko menemukan rujukan empirisnya pada aksi protes Femen ketika memotong dan merobohkan salib raksasa di pusat kota Kiev, Ukraina sebagai simbol perlawanan terhadap penangkapan Pussy Riot band di Rusia. Hal ini dilakukan karena Pussy Riot melakukan perunjukan di Gereja Moscow's Cathedral of Christ the Savior pada 21 Februari 2012 dengan menyampaikan musiak yang mengandung lirik yang pro terhadap feminism LGBT rights, dan oposisi terhadap Presiden Rusia Vladimir Putin dengan member label diktator pada setiap pertunjukannya (Cadwalladr 2012).

Bentuk pelawanan terhadap opresi institusi dan nilai keagamaan ini dilandasi oleh pemahaman bahwa pada dasarnya ajaran-ajaran keagamaan mendegradasi identitas perempuan sebagai bagian dari human-being. Mengutip Shevchenko (2015b),

\begin{abstract}
"Religious texts say that a God created a man's body and infused a soul inside, whereas the woman's body was made out of a man's rib. This 'belief' has caused serious debates about whether women are human beings or simply bodies with mysterious abilities, without a soul, which sparkled into the Catholic Church a few centuries ago. This was also one of the reasons for the long-term massacres against women known as "witch-hunts," when women were tortured and burned alive simply for being women, an evil powerful creation that threatened the development of a man's world.
\end{abstract}

Pemahaman ideologis Femen terhadap institusi dan nilai-nilai keagamaan terkait relasinya dengan identitas perempuan dapat diinterpertasi dari kutipan tersebut. Ajaran agama, dalam hal ini agama Kristen dan Katolik yang diprotes oleh Femen, memposisikan perempuan sebagai subordinasi dari identitias laki-laki. Risalah keagamaan yang menyebutkan bahwa perempuan diciptakan dari tulang rusuk laki-laki dianggap sebagai sumber opresi terhadap perempuan. Hal ini membentuk diskursus bahwa posisi perempuan adalah subordinasi terhadap laki-laki karena merupakan bagian dari tubuh lakilaki. Praktik-praktik keagamaan semacam ini yang kemudian diprotes oleh Femen sebagai gerakan yang mengklaim diri ateis dan sekular dalam merespon institusi dan nilai-nilai agama.

Sextrimisme yang diklaim sebagai ideologi Femen setidaknya menggunakan cara pandang tersebut. Dalam wawancara dengan Douglas Herbert, Inna Shevchenko mengatakan jika Femen tidak hanya anti Islam atau Kristen, melainkan anti dengan semua praktik keagamaan yang berakibat opresi terhadap perempuan (Shevchenko 2013d). Lebih lanjut dijelaskan Shevchenko dalam wawancara yang sama bahwa Femen tidak mempermasalahkan cara-cara orang 
beribadah atau sistem kepercayaan yang dianut, yang diprotes adalah jika agama sudah dipraktikan di ruang publik yang berujung pada opresi terhadap perempuan. Hal ini mengindikasikan bahwa Femen bukan organisasi Islamphobia atau Kristenphobia, melainkan menentang nilainilai yang mengopresi perempuan walaupun itu nilai-nilai keagamaan. Setelah menjelaskan tentang keberatannya terhadap persepsi mengenai nilai-nilai opresif dalam agama, Femen mengkritik mengenai industry seks sebagai manifestasi dasar dari sistem sosial patriarki.

Poin ketiga yang mendasari Femen mendefinisikan patriarki adalah adanya industri seks yang terdiri dari perempuan sebagai komoditas utama. Interpretasi yang muncul dari pernyataan Shevchenkon tersebut adalah dalam gerakan ini poin yang menjadi sasaran tidak hanya industri prostitusi, melainkan juga setiap model industri yang memposisikan tubuh perempuan sebagai objek seksual. Tujuan dari Femen terkait dengan industri seks adalah untuk menggunakan tubuh perempuan yang selama ini menjadi komoditas seks, untuk menyampaikan pesan politik yang mereka bawa dalam hal ini pesanpesan radikal terhadap pembebasan perempuan. Hal ini direpresentasikan dalam kutipan pernyataan kedua yang menyatakan bahwa perjuangan akan berakhir jika otoritas terhadap tubuh telah menjadi milik mereka.

\section{Posmodern Strategy: Tubuh Perempuan Sebagai Alat Protes}

Femen memposisikan diri sebagai soldier of feminism sebagai identitas pergerakannya (Shevchenko 2013e). Mengutip Inna Shechenko, "You are not a model, you are not gonna show how beauty you are, you are a soldier" (Shevchenko 2013e). Artikulasi mengenai identitas soldier of feminism dapat dilihat dari tiga hal, yang pertama dari cara protes yang dilakukan yaitu dengan facing the enemy face to face (Shevchenko 2013d), dengan menggunakan tubuh sebagai media protesnya dan persepsi terhadap opresi perempuan sebagai perang antar gender. Hal ini dilakukan dengan tujuan untuk menyebarkan ide-ide pergerakan Femen tepat ditempat yang diinginkan, right in that place through the object (Shevchenko 2013e).

Strategi yang pertama adalah dengan cara berada sedekat mungkin dengan sasaran protes dan meneriakan poin protes di depan sasaran objek, seperti fuck off, dictator!", "I'm not your sex toy!", atau "religion is slavery!" (Shevchenko 2015c). Cara ini digunakan ketika Femen memprotes beberapa pemimpin dunia, seperti Presiden Rusia Vladimir Putin, Kanselir Jerman Angela Merkel, Pemimpin Katolik Paus Fransikus dan Perdana Menteri Italia Sylvio Berlusconi. Strateginya adalah dengan menuliskan slogan protes di tubuh bagian atas 
perempuan dan kemudian melakukan aksi telanjang dada di depan target protes.

Penggunaan tubuh perempuan merupakan salah satu model posmodern strategi. Terlepas dari perdebatan mengenai dimensi ontologinya, strategi ini setidaknya mengedepankan dua hal efek kejut dan dimensi atraktif dari discourse yang dibangun (Rallonza 2014, 257; Shevchenko 2013d). Dalam pandangan Shevchenko, penggunaan tubuh sebagai alat protes adalah yang paling efektif. Tubuh perempuan dipersepsi sebagai pusat struktur patriarki yang mengopresi perempuan melalui seksualitas. Hal ini yang dijadikan counter attack terhadap patriarki. Dengan menggunakan tubuh perempuan sebagai penyampai pesan, Femen menganggap telah menyerang pusat dari struktur patriarki dan melepaskan topeng yang menyembunyikan praktik opresi terhadap perempuan oleh tiga hal, diktatorisme, institusi agama dan industri seks. Menurut Shevchenko (2013d),
"We are not denying our potential to be treated as sex objects. On the contrary, we are taking our sexuality into our own hands, turning it against our enemy. We are transforming female sexual subordinasiion into aggression, and thereby starting the real war."

Statement Shevchenko di atas merepresentasikan konsep penggunaan tubuh perempuan sebagai alat protes, sebagai senjata. Interpertasi yang muncul adalah bahwa tubuh perempuan dimakna sebagai objek seksual telah menjadi praktik umum yang hampir tidak terhindarkan. Namun kondisi ini justru memberi keuntungan terhadap perjuangan pembebasan perempuan untuk mendapatkan posisi yang strategis, sebagai pusat perhatian dari masyarakat yang patriarki. Oleh karena itu sebagai pusat perhatian akan lebih mudah menyebarkan ide-ide perjuangan yang dibawa dengan menggunakan tubuh perempuan sebagai pusat seksualitas. Ide dasarnya adalah dengan mengubah pemahaman terhadap tubuh perempuan dari yang awalnya objek seksual menjadi senjata perjuangan yang otonom dimiliki oleh perempuan.

Artikulasi diskursus mengenai tubuh perempuan sebagai senjata perjuangan terkait dengan pemahaman bahwa relasi antar gender, perempuan dan laki-laki adalah model perang. Beberapa artikulasi dari Inna Shevchenko dan Aleksandra Shevchenko mengandung interpretasi terhadap hal ini. Ketika Presiden Ukraina Viktor Yanukovich terpilih menjadi Presiden Ukraina pada tahun 2010, Femen pertama kali menggunakan istilah war untuk menggambarkan protes mereka kedepan."Five Femen activists, topless for the first time, broke into a voting poll with slogans saying: "The war will start soon..." (Shevchenko 2014). Diskursus ini juga terkandung dalam artikulasi pernyataan 
Shevchenko yang ditulis,"Femen is at war with a patriarchy that sees women as sex objects. What weapons do we have? Our bare breasts." (Shevchenko 2015c) Keterkaitan antara konsep war dan weapon mengindikasikan bahwa Femen menegaskan juktaposisi antara feminisme dan patriarki, tubuh perempuan dengan tubuh laki-laki. Tubuh perempuan sebagai senjata menegaskan anggapan perang terhadap patriarki. Hal ini dikuatkan dengan penjelasan selanjutnya, "make no mistake about it: we are at war. This is an ideological war, a war of traditionalism against modernity, oppression against freedom, dictatorship against the right to free expression (Shevchenko 2015c)."

\section{Interpretasi Nilai-Nilai Posmodern Feminisme Dalam Protes Femen}

Penjelasan di atas mengenai Femen setidaknya mengindikasikan nilainilai yang dijelaskan oleh feminisme posmodern dalam pergerakan Femen. Percabangan permikiran feminisme posmodern berfokus pada discourse mengenai tubuh (Tong 1998, 283). Secara diskursif tubuh perempuan diopresi secara kebudayaan oleh patriarki melalui discourse tentang falus. Feminisme Posmodern memandang tubuh perempuan sebagai objek yang direpresi oleh keberadaan falus (Cixous 1981, 41). Hal ini kemudian menyebabkan pemaknaan tubuh perempuan menjadi identitas liyan yang eksistensi dan pemaknaannya ditentukan oleh pemilik falus.

Pemikiran terebut berimplikasi pada munculnya discourse dari feminis posmodern yang menyatakan bahwa tubuh perempuan harus dikuasai secara otonom oleh perempuan, bukan sebagai identitas yang subordinasi terhadap falus (Rubin dalam Reiter 1975, 276). Dalam kaitannya terhadap gerakan sosial perempuan, tubuh perempuan tidak lagi menjadi barang yang sifatnya privat melainkan bergeser menjadi identitas yang sifatnya publik. Hal ini dapat diinterpretasikan melalui berkembangnya gerakan protes yang menggunakan tubuh sebagai alat untuk menyampaikan pesan dalam konteks pergerakan perempuan. Argumen feminisme posmodern adalah bahwa tubuh bukan lagi barang privat melainkan alat perlawanan terhadap struktur yang represif, karena tubuh perempuan seharusnya berada di bawah otonomi penuh perempuan.

Otonomi yang diinterpretasi feminis posmodern terhadap tubuhnya dapat ditemui dalam pola-pola protes Femen. Cara-cara yang dilakukan Femen secara ideologis setidaknya mencakup tiga hal, yakni demokratis, ateis dan menjadikan seksualitas sebagai senjata perjuangan untuk kemudian menyerang sistem yang dianggap patriarki dengan menggunakan komoditas utama dari sistem tersebut yakni seksualitas 
perempuan. Pilihan strategi Femen untuk menggunakan tubuh sebagai senjata perlawanan terhadap patriarki adalah manifestasi dari pemikiran feminisme posmodern dalam kuadran feminisme gelombang kedua. Hal ini didasari kesesuaian antara interpretasi mengenai dekonstruksi makna tubuh yang otonom dan konsep awal dekonstruksi Derrida terhadap logosentrisme yang diadopsi oleh pemikiran feminisme posmodern yang mendekonstruksi falogosentrisme.

Linearitas pemikiran di atas kemudian termanifestasi dalam cara-cara yang dilakukan oleh Femen sebagai gerakan perempuan. Strategi pergerakan yang siaftnya diskursif, ciri khas posmodern, diterjemahkan dalam setidaknya tiga hal, yakni facing the enemy face to face (Shevchenko 2013d), protes menggunakan tubuh telanjang dan persepsi mengenai gender war. Ketiga model protes tersebut bermuara pada satu value yakni offensive protest. Model offensive protes dapat diinterpertasi sebagai manifestasi semangat pembebasan feminisme gelombang kedua. Hal ini didasarkan pada asumsi bahwa feminisme gelombang kedua merupakan model perlawanan terhadap opresi patriarki.

Asumsi ini berimplikasi pada sifat dasar feminisme gelombang kedua yang menyiratkan bahwa perempuan adalah identitas yang kuat, otonom dan mampu menggunakan kekuatannya secara mandiri untuk melawan opresi patriarki serta mengambil peran yang signifikan dalam interaksi sosial (Shoemaker 1997, 116). Manifestasi dari semangat tersebut oleh Femen adalah bahwa gerakan protes perempuan selama ini cenderung berada dalam logika falus. Terlalu lembut, powerless dan kurang destruktif terhadap struktur patriarki. Mengutip Inna Shevchenko, to fight patriarchy is to become soldier of feminism, not just study it accademically, we practice it on the street (Shevchenko 2013d). Hasilnya adalah Femen menggunakan tubuh perempuan yang dipersepsi sebagai simbol seksualitas pusat dari struktur yang patriarki untuk menyampaikan pesan politik mengenai opresi yang dipersepsi dialami oleh perempuan. Dengan menggunakan strategi yang sifatnya ofensif dan destruktif terhadap simbol opresi.

\section{Pergeseran Discourse Identitas Perempuan Ukraina Masa Pos-Soviet}

Pada masa pasca Soviet, identitas permpuan di Ukraina memiliki dua spektrum, yakni identitas berehynia dan barbie. Berehynia membentuk pemahaman bahwa perempuan ditakdirkan untuk sekuat tenaga menjaga wilayahnya. Pemahaman yang muncul adalah bahwa perempuan Ukraina harus menjadi ibu rumah tangga dan menjaga keluarganya dalam berbagai bidang untuk merepresentasikan nilai-nilai 
patriotik Berehynia (Jevgrafova 2014, 23). Mengutip Kis, "the woman's supreme mission is the physical and cultural reproduction of the nation through appropriate nurturing of children, a mission which is fulfilled by every genuine Ukrainian woman (Kis 2005, 109).

Spektrum identitas perempuan di Ukraina pasca Soviet setidaknya melibatkan discourse mengenai businesswomen. Image mengenai perempuan tangguh yang dapat menjadi breadwinner bagi keluarga adalah diskursus yang diartikulasikan dalam identitas ini (Zhurzhenko 2001, 41). Identitas ini muncul karena setidaknya dual hal, yakni warisan pemahaman tradisional mengenai perempuan jaman Soviet sebagai pekerja dan konstruksi media mengenai image sukses perempuan wirausaha (entrepreneur) (Zhurzhenko 2001, 41) .

\section{Penolakan Terhadap Barbie Life Style}

Ketika ideologi komunis runtuh beserta Uni Soviet, dunia didominasi oleh model-model westernisasi, tidak terkecuali bekas negara Soviet. Dalam konteks Ukraina, tahun 1990 awal merupakan tahun ketika akses terhadap pasar mulai dibuka sehingga timbul gejala peningkatan konsumsi di masysrakat Ukraina (Jevgrafova 2014, 29). Peningkatan konsumsi ini kemudian diikuti dengan masuknya barang-barang mewah dan merek terkenal ke dalam pasar Ukraina. Invasi pasar di Ukraina tidak dilakukan oleh perusahan produsen saja, melainkan juga besama denga instrumen pasar. Perusahaan besar masuk bersama dengan instrumen iklannya, sehingga menimbulkan pola-pola konsumsi baru di Ukraina. Kis mengusulkan terminology Barbie untuk menyebut pandangan ini sejenis dengan beautifull expensive doll (Kis 2005, 119). Pandangan mengenai sosok wanita ideal menurut konsep Barbie bertentangan dengan pandangan mengenai konsep berehynia. Barbie feminity lebih banyak mengasosiasikan diri sebagaia bagian dari kultur barat. Hal ini didsarkan pada diskursus bahwa kalangan ini lebih memilih mengasosiasikan diri sebagai "pretty", "chic", "idle", "fashionable", "sexually attractive", dari pada mengasosiasikan diri terhadap sosok berehynia (Jevgrafova 2014, 29).

\section{Globalisasi Informasi sebagai Model Westernisasi}

Pasca perang dingin, globalisasi diidentifikasi sebagai dua hal, yang pertama adalah perkembangan teknologi informasi (Castells 1996) dan praktik-praktik westernisasi (Scholte 2000). Kedua elemen ini seperti dijelaskan disebelumnya membentuk dua polaritas diskursus yang terindentifikasi di Ukraina, yakni berehynan dan Barbie. Dalam konstestasi diskursus mengenai identitas perempuan di Ukraina, 
identitas berehynian dipersepsi sebagai identitas yang muncul dari bawah. Kesadaran historis dan nilai-nilai tradisional perempuan Ukraina direpresentasi melalui mitologi berehynian sehingga kemudian memunculkan konstruksi mengenai model feminine yang ideal di Ukraina. Di sisi yang lain, identitas Barbie, yang merujuk pada seksualitas perempuan sebagai penanda kondisi feminine adalah hasil dari dialektika westernisasi hasil demokratisasi di Ukraina. Identityi ini memunculkan gaya hidup yang merujuk pada konsumerisme.

Konstruksi tersebut dibangun oleh diskursus melalui media yang menanamkan nilai barat di Ukraina. Mayoritas media di Ukraina, khususnya yang memuat mengenai kehidupan perempuan cenderung bersifat seksis. Hal ini berkaitan dengan artikel dan pemberitannya yang menonjolkan seksualitas perempuan dengan mengekspose tubuh dan life style konsumerisme (Kis 2005, 121). Studi Marushevska dan Sharova menyimpulkan bahwa dalam majalah popular Ukraina, Facts and Comments, discourse mengenai perempuan digambarkan sebagai "a woman is regarded as a decoration, a doll, a man's property $t$...1 without personality, without name, dependent on men's status only (Marushevska dan Sharova 2001, 224). Argumen dari Marushevska dan Sharova bahwa mayoritas discourse mengenai perempuan Ukraina yang tercermin dari pemberitaan majalah populer adalah sebagai subordinasi dari perempuan. Hal ini kemudian menunjukan permasalahan gender yang ada di Ukraina, bahwa perempuan selalu dikonstruksi, setidaknya oleh media untuk memposisikan diri sebagai subordinasi bagi laki-laki. Konstruksi media selanjutnya adalah bahwa tugas utama perempuan untuk menemukan pasangan laki-laki yang tepat (Kis 2005, 121). Hal ini dikonstruksi melalui publikasi populer media mengenai kehidupan sehari-hari perempuan. Salah satu yang populer adalah buku terbitan Elena Yakovlevna Sheynina dan E. Levinshtein yang berjudul Encyclopedia For Girl. Buku ini berisi mengenai cara-cara hidup perempuan muda. Secara spesifik membahas mengenai permasalahan perempuan usia muda seperti cara mendapatkan pacar yang cocok, petunjuk untuk mendapatkan wajah dan tubuh awet muda serta caracara untuk menyelesaikan permasalahn hidup remaja (Kis 2005, 121122).

\section{Kritik Terhadap Posfeminisme}

Posfeminisme sering dikaitkan dengan era pasca 1990 (Faludi 1992). Pada masa ini posfeminisme dipopulerkan melalui diskursus media populer. Pandangan posfeminisme tidak muncul dari suatu aksi revolusioner atau monumental, melainkan melalui pengenalan istilah dari media (Kavka 2002). Secara terminologis, posfeminisme muncul pada kisaran tahun 1982 yang diinsiasi oleh pemberitaan media. 
Secara umum argumen utama dalam posfeminisme adalah bahwa struktur organisasi pergerakan yang menggunakan label feminisme terbukti tidak efektif (Whittier 1995). Permasalahan-permasalahan mengenai perempuan tidak menemui solusi yang signifikan dalam perkembangan protes feminisme. Berangkat dari klaim terhadap kegagalan feminisme, posfeminisme muncul menawarkan argumen yang berbeda dari feminisme. Bahwa perempuan tidak harus berada diluar struktur yang patriarki untuk melakukan perlawanan, melainkan bergerak naik dalam sistem yang opresif, dalam bahasa Natsha Walter disebut sebagai celebratory and optimistic movement (Walter 1999).

Posfeminisme secara ideologis melihat bahwa pergerakan perempuan tidak seharusnya destruktif dengan menggunakan pergerakan politik, melainkan dengan memanfaatkan nature kewanitaan yang dibayangkan sebagai sifat-sifat lembut yang dimiliki perempuan. Dalam pemahaman Showden disampaikan bahwa "women abuse the power that comes with these "sugar and spice and all that's nice" assumptions to render men" (Showden 2009). Argumen tersebut menunjukan secara ideologis pergerakan perempuan yang destruktif tidak menjadi poin utama dalam posfeminisme, karena hal tersebut dipandang menegasikan nature perempuan yang lembut.

Secara ideologis, pandangan posfeminisme juga menolak adanya tujuantujuan pembebasan perempuan. Seperti disampaikan Susan Bollotin (1982), the battle for equality has been won, and it is time to stop "harping" on women's oppression. Pernyataan Bollotin tersebut mengindikasikan bahwa posfeminisme berbeda dengan feminisme dalam hal tujuan, ketika feminisme bertjuan untuk melakukan politik pembebasan terhadap perempuan dari struktur yang patriarki (Wolf 1993), posfeminisme menganggap perjuangan pembebasan perempuan telah berakhir dan dimenangkan oleh identitias perempuan. Dalam konteks kekinian yang tersisa adalah perjuangan untuk melakukan ekspresi yang variatif dengan tetap berepegang pada nilai-nilai kewanitaan. Hal ini seperti diungkapkan oleh Wolf (1993), "believes women deserve to feel that the qualities of starlets and queens, of sensuality and beauty, can be theirs."

Secara umum fokus utama dari posfeminisme adalah hendak mengatakan bahwa perjuangan yang dilakukan oleh feminisme telah usang. Kesetaraan telah dimenangkan dan perempuan harus melangkah lebih jauh. Mengutip Gamble (1998), 'We're all "post-feminist" now, they assert, meaning not that women have arrived at equal justice and moved beyond it, but simply that they themselves are beyond even pretending to care.' 


\section{Opresi Identitas Perempuan Sebagai Fasilitator Munculnya Femen}

Klaim ideologis posfeminisme bahwa opresi terhadap perempuan tidak lagi terjadi hanya karena diskursus mengenai keterbukaan akses pekerjaan dan pendidikan terhadap perempuan. Hal ini menjadi dasar argumen posfeminis untuk menyatakan bahwa perjuangan perempuan pada masa feminisme gelombang kedua tidak lagi relevan. Bentukbentuk aktivisme gelombang kedua dengan turun ke jalan, dengan menggunaka tubuh perempuan tidak lagi dipandang relevan. Alasannya adalah karena tidak lagi ada struktur patriarki yang mengekang perempuan. Perempuan sudah memangkan pertarungan gelombang kedua melawan patriarki (Bollotin 1982).

Klaim ini bermasalah ketika dihadapkan pada kenyataan pandangan feminisme gelombang kedua menemukan bentuk barunya dalam pergerakan perempuan telajang dada. Gerakan ini mulai banyak muncul justru di era diskursus mengenai posfeminisme menjadi mainstream perdebatan. Femen salah satu yang menginternalisasi dan mengartikulasikan semangat feminisme gelombang kedua mengkonfirmasi satu hal yang bertentangan dengan klaim posfeminis. Bahwa patriarki masih menjadi struktur yang membelenggu perempuan sebagai identitas liyan dari laki-laki.

Dalam konteks Ukraina, karena dalam konteks Ukraina model represi yang diakibatkan struktur yang patriarki terbagi menjadi dua dimensi, yakni kekerasan yang sifatnya fisik dan simbolik. Model opresi terhadap perempuan dari segi simbolik adalah sepeti yang dijelaskan di bab sebelumnya yakni melalui konstruksi identitas yang diskursif terhadap domestifikasi dan diskriminasi perempuan. Sedangkan opresi secara fisik dapat dilihat melalui data-data statistik. Sebagai contoh dalam awal tahun 2005, tahun yang diklaim sebagai bagian dari diskursus posfeminisme, terdapat 83.150 laporan kekerasan dalam rumah tangga yang terjadi di Ukaina. Laporan ini kemudian direspon oleh Department of Public Safety of the Ministry of Internal Affairs Ukraina dengan menyatakan bahwa 90\% korban dari laporan tersebut adalah perempuan (Amnesty Interasional 2996). Dari sumber yang sama, disampaikan bahwa pada tahun selanjutnya, 2006, di Ukraina terjadi 1008 kasus pembunuhan berencana dan 402 kasus pembunuhan tidak berencana dimana yang menjadi korban mayoritas perempuan. Pada tahun 2001 survey oleh Winrock International menyatakan bahwa dari 6000 orang repsonden perempuan di Ukraina yang berumur 12-30 tahun, 33\% pernah mengalami kekerasan simbolik berupa kata-kata. 11$12 \%$ mengalami pelecehan seksual dan $5 \%$ dari responden mengalami kekerasan fisik yang sebagian besar dilakukan oleh suami (Amnesty Internasional 2006). Dalam sumber yang sama disampaikan terjadi 
paksaan terhadap perempuan d Ukraina untuk bekerja di luar negeri yang berujung pada human trafficking. Parahnya, 80\% dari perempuan korban trafficking adalah perempuan yang sebelumnya pernah mengalami kekerasan dalam rumah tangga atau dari lingkingan sekitarnya.

Apa yang kemudian memunculkan Femen sebagai gerakan protes dengan ciri feminisme posmodern? Setelah melalui penjelasan dan analisis diskursus sebelumnya maka kesimpulannya adalah pandangan mengenai eksistensi patriarki. Eksistensi praktis opresi terhadap identitas perempuan. Ideologi sextrimisme yang diartikulasikan oleh Femen jika mengikuti logika Caffereta (1982) di atas tidak akan terbentuk dari ruang kosong. Ada proses konstruksi dan rekonstruksi dari setting sosial yang melatar belakangi pergerakan. Hal ini dapat dilacak dari setting sosial ketika tiga pendiri awal Femen, Oksana Shachko, Anna Hutsol and Aleksandra Shevchenko tinggal.

Dalam konteks Internasional, munculnya Femen sebagai fenomena pergerakan perempuan lintas negara sekaligus memposisikan klaim posfeminisme terhadap kemenangan perempuan terahdap opresi patriarki tidak sepenuhnya benar. Mengikuti logika tersebut, maka kemudian silogisme pemikirannya menjadi dimana ada resistensi Femen, disitu terdapat opresi terhadap perempuan. Berdasarkan silogisme ini kemudian berkembangnya Femen ke berbagai negara dapat dibaca sebagai kegagalan klaim posfeminisme terhadap absennya struktur yang patriarki.

\section{Simpulan}

Penjelasan di atas setidaknya membuat klaim posfeminisme terhadap absennya struktur patriarki dalam era pasca 1990 tidak sepenhnya benar. Kemenangan perempuan yang digaungkan posfeminisme tidak terbukti seetidaknya di Ukrainea, Brazil, Iran serta negara-negara lain dimana Femen melakukan gerakan protesnya. Hal ini mengikuti silogisme yang telah dijelaskan sebelumnya bahwa memposisika Femen sbegai geakan protes akan diikuti mengenai persepsi mengenai ada praktik-praktik opresi terhadap perempuan di wilayah tersebut. Hal ini kemudian memunculkan pertanyaan lebih jauh, pola interaksi masyarakat seperti apa yang memunculkan pandagan mengenai posfeminisme sehingga klaim posfeminimse adalah absennya struktur yang opresif terhadap perempuan?

Bagian ini setidaknya mengkonfirmasi dua hal, yang pertama bahwa klaim mendasar argumenasi posfeminisme mengenai opresi terhadap perempuan oleh struktur yang patriarki. Dan yang kedua kemunculan 
Femen berasal dari persepsi mengenai opresi diberbagai wilayah. Kedua premis tersebut membentuk silogisme, ketika terjadi protes oleh Femen dan mungkin gerakan social sejenisnya, maka sebelumnya terdapat persepsi terhadap opresi perempuan. Hal ini kemudian mengindikasikan lemahnya klaim posfeminisme yang hanya didasarkan pada disoucrse keterbukaan akses terhadap pekerjaan dan pendidikan ole perempuan, sedangkan secara empiris dan diskursif, masih terjadi opresi terhadap perempuan oleh struktur patriarki.

\section{Daftar Pustaka}

\section{Buku dan Artikel Jurnal}

Arkhipenko, Viktoriya. 2012. Reconsidering The Conventional Private/Public Dichotomy: Examining The Femen Movement Through The Arendtian Lens of the Social. Magister Tesis. Departement of International Relations and European Studies. Central European University: Budapest.

Bollotin, Susan. 1982. Voices From the Post-feminist Generation. New York Times Magazine. October (17).

Bollotin, Susan. 1982. Voices From the Post-feminist Generation: New York Times Magazine. October (17).

Cafferata, Gail L. 1982. The Building Of Democratic Organizations: An Embryological Metaphor. Administrative Science Quarterly (27).

Castells, Manuel. 1996. "The Information Technology Revolution", dalam the Rise of the Network Society, Oxford: Blackwell Publisher.

Cixous, Helene dan Catherin Clement. 1986. The Newly Born Woman. Minneapolis: University of Minnesota Press.

Faludi, Susan. 1992. Backlash. London: Vintage.

Jevgrafova, Galina. 2014. Gender Issue And The Process Of NationBuilding: The Case Of Ukraine. Tesis Master. University of Tartu , Faculty of Social Sciences and Education, Institute of Government and Politics.

Kaneva, Nadia dan Elza Ibroscheva. 2014. Pin-Ups, Strippers And Centerfolds: Gendered Mediation And Post-Socialist Political Culture. European Journal of Cultural Studies.

Kavka, Misha. 2002. Feminism, Ethics, and History, or What Is the "Post" in Postfeminism?.Tulsa Studies in Women's Literature 21 (1).

Kavka, Misha.2002. Feminism, Ethics, and History, or What Is the "Post" in Postfeminism? Tulsa Studies in Women's Literature 21 (1).

Kis, Oksana. 2005. "Choosing Without a Choice: Dominant Models of Femininity in Contemporary Ukraine”. ed. Asztalos Morell, et al. 
Gender Transitions in Russia and Eastern Europe. Stockholm: Gondolin Publishers: 106.

Kis, Oksana. 2007. Beauty Will Save the World: Feminine Strategies in Ukrainian Politics and the Case of Yulia Tymoshenko. Spaces of Identity 7 (2): 31-75.

Olena, Marushevska and Ksenia Sharova. 2001. The Image of Woman in the Ukrainian Press: The Case of Newspaper Facts and Comments. Kyiv: Stylos.

Osgerby, Bill. 2001. Playboys in Paradise: Masculinity, Youth and Leisure-Style in Modern America.Oxford: Berg.

Pitzulo, Carrie. 2008. The Battle in Every Man's Bed: Playboy and The Fiery Feminist. Journal of History and Sexuality 17(2).

Rallonza, Ma. Lourdes Veneracion. 2014. Women's Naked Body Protests And The Performance Of Resistance: Femen And Meira Paibi Protests Against Rape. Philippine Political Science Journal, 35 (2).

Rubin, Gayle. "The Traffic in Women" dalam Rayna R. Reiter. 1975. ed. Toward an Anthro-pology of Women. New York: Monthly review Press.

Sarah Ashwin. 2000. Gender, State and Society in Soviet and PostSoviet Russia. London; Routledge.

Shoemaker, L. 1997. Part animal, part machine: Self-definition, Rollins style. Dalam L. Heywood \& J. Drake (Eds.), Third wave agenda: Being feminist, doing feminism . Minneapolis: University of Minnesota Press.

Showden, Carisa R. 2009. What's Political about the New Feminisms?. Frontiers: A Journal of Women Studies, 30 (2).

Sutton, Barbara. 2007. Naked Protests: Memories of Bodies and Resistance in the World Social Forum." Journal of International Women's Studies 8 (3).

Tong, Rosemarie Putnam. 1998. Feminist Thought A Very Comprehensive Introduction. Colorado:Westview Press.

Walter, Natasha. 1999. The New Feminism. London: Virago Press.

Whittier, Nancy. 1995. Feminist Generations: The Persistence of the Radical Women's Movement.Philadelphia: Temple University Press.

Wolf, Naomi. 1993. Firewith Fire: The New FemalePower and How It Will Change the 21st Century. New York: Random House.

Zhurzhenko, Tatiana. 2001. Free Market Ideology and New Women's Identities in Post-socialist Ukraine. The European Journal of Women's Studies 8(1).

\section{Artikel Online}

Amnesty International. "Ukraine: Domestic Violence - Blaming the Victim". 2006 [online] dalam 
http://www.amnesty.org/en/library/asset/EUR5o/o05/2006/en/6 92d5294-d3d711dd-8743d305bea2b2c7/eur500052006en.pdf diakses pada 15 Juni 2015.

Bacchi, Umberto. 2013. Ukraine: Topless Femen Activists' Dirty Protest against President Yanukovich [online] dalam http://www.ibtimes.co.uk/femen-ukraine-protest-topless-peeyanukovich-paris-526839 diakses pada 12 Juni 2015.

Bennet, Marc.2014. Russia's Anti-Gay Law Is Wrong - But So Is Some Of The Criticism From The West [online] dalam http://www.theguardian.com/commentisfree/2014/feb/o5/russiaanti-gay-law-criticism-playing-into-putin-hands diakses pada 11 juni 2015.

Cadwalladr, Carole. 2012. Pussy Riot: Will Vladimir Putin Regret Taking On Russia's Cool Women Punks? [online] dalam http://www.theguardian.com/world/2012/jul/29/pussy-riotprotest-vladimir-putin-russia diakses pada 11 Juni 2015.

Connoly, Kate. 2013. Femen Activist Tells How Protest Against Putin And Merkel Was Planned [online] dalam http://www.theguardian.com/world/2013/apr/12/femen-activistprotest-putin-merkel diakses pada 11 Juni 2015.

Gamble, Sarah. 1998. The Routledge Companion To Feminism And Postfeminism. London Routledge.

Shevchenko, Aleksandra. 2013a. Femen is The New Feminism [online] dalam https://www.youtube.com/watch?v=FD9pSqUY-do diakses pada 16 Juni 2015.

Shevchenko, Inna. 2013c. Sextremism Feminism [online] dalam https://www.youtube.com/results?search_query=femen+interview diakses pada 11 Juni 2015.

Shevchenko, Inna. 2013e. The Interview - Inna Shevchenko, Femen Activist [online] dalam https://www.youtube.com/watch?v=d_yBPTbPOPs diakses pada 11 Juni 2015.

Shevchenko, Inna. 2013b. Why Topless Protesters Will Hound Islamic Leaders [online] dalam http://www.innashevchenko.com/2013/04/22/why-topless-protesters-will-houndislamic-leaders-cnn/ diakses pada 11 Juni 2015.

Shevchenko, Inna. 2015. 'Are You Normal, Or A Lesbian?': How Moroccan Morons Attempted To Silence Our Gay Rights Protest [online] dalam http://www.ibtimes.co.uk/are-you-normal-lesbianhow-moroccan-morons-attempted-silence-our-gay-rights-protest1505237 diakses pada 15 Juni 2015.

Shevchenko, Inna. 2015b. I Fight For The Day When Society Feels Guilty For Its Ideas About Women's Bodies", Sheramag [online] dalam http://www.inna-shevchenko.com/2015/05/24/i-fight-forthe-day-when-society-feels-guilty-for-its-ideas-about-womensbodies-sheramag/ diakses pada 11 Juni 2015. 
Shevchenko, Inna. 2015a. On Femen Manifesto [online] dalam http://www.inna-shevchenko.com/2015/05/03/on-femenmanifesto/ diakses pada 11 Juni 2015.

Shevchenko, Inna. 2015c. We Are Femen, The Naked Shock Troops Of Feminism [online] dalam http://www.innashevchenko.com/2015/01/16/we-are-femen-the-naked-shocktroops-of-feminism-the-guardian/ diakses pada 12 Juni 2015.

Shevchenko, Inna.2014. Femen On Protests In Kiev: 'Now, It's Fight Or Die' [online] dalam http://www.innashevchenko.com/2014/o3/16/femen-on-protests-in-kiev-now-itsfight-or-die-dazed/ diakses pada12 Juni 2015 